\section{Effect of priming and different types of drying on the physiological quality of Urochloa ruziziensis seeds}

\author{
Giselle Márcia de Melo ${ }^{1}$ (D) , Heloisa Oliveira dos Santos*2 ${ }^{(D)}$, Thaísa Fernanda \\ Oliveira $^{1}$ (D) Antonio Rodrigues da Cunha Neto ${ }^{1}$ (D), Aline Aparecida Silva \\ Pereira $^{3}$ (D), Marilia Mendes dos Santos Guaraldo ${ }^{1}$
}

ABSTRACT: Seed vigor is one of the main limitations to meet the demanding forage market. In order to boost the productive potential and provide the satisfactory development of quality seeds and seedlings, it is necessary to develop techniques that provide quality and high productivity. With the Urochloa genus stands out in the seed production and quality, this study aimed to evaluate the effect of seed priming with sodium nitroprusside and to define the best drying method that allows the maintenance of the changes of this treatment in Urochloa ruziziensis seeds. The seeds were conditioned in sodium nitroprusside solution, as a nitric oxide donor, for 42 hours and later submitted to the following procedures: no drying, initial reduction of water content, thermal shock, slow and fast drying. The design was completely randomized, with ten treatments and four replications. Water content, germination, emergence and biochemical evaluations were performed. As results, it was observed that all drying methods evaluated reduced the water content of the seeds to $12 \%$, recommended range for storage, with the exception of the treatment without drying that presented $30 \%$. Regarding germination parameters, the treatment of initial reduction and quick drying obtained the best performance in germination and emergence. Moreover, the types of drying presented high rate of enzymatic activity of the antioxidant system, thus helping in the maintenance of redox homeostasis. According to the enzymatic activity and germination rates, it suggests that the rapid drying method after priming with nitric oxide is the best method for Urochloa ruziziensis.

Index terms: seed quality, sodium nitroprusside, osmotic priming.

RESUMO: O vigor de sementes é uma das principais limitações para atender ao exigente mercado de forrageiras. A fim de impulsionar o potencial produtivo e propiciar o desenvolvimento satisfatório de sementes e mudas de qualidade, é necessário desenvolver técnicas que propiciem qualidade e alta produtividade. Tendo o gênero Urochloa destaque na produção e qualidade de sementes, este trabalho teve como objetivo avaliar o efeito do condicionamento fisiológico de sementes com nitroprussiato e definir o melhor método de secagem que permita a manutenção das alterações deste tratamento em sementes de Urochloa ruziziensis. As sementes foram condicionadas em solução de nitroprussiato de sódio, como um doador de óxido nítrico, por 42 horas e posteriormente submetidas aos procedimentos: sem secagem, redução inicial do teor de água, choque térmico, secagem lenta e rápida. $O$ delineamento foi inteiramente casualizado, com dez tratamentos e quatro repetições. Foram realizados teste de teor de água, germinação, emergência e avaliações bioquímicas. Como resultados, foi observado que todos os métodos de secagem avaliados reduziram o teor de água das sementes a $12 \%$, faixa recomendada de armazenamento, com exceção do tratamento sem secagem que apresentou $30 \%$. Com relação aos parâmetros germinativos, o tratamento de redução inicial e secagem rápida obteve melhor desempenho na germinação e emergência. Além disso, os tipos de secagem apresentaram alta taxa de atividade enzimática do sistema antioxidante, auxiliando assim na manutenção da homeostase redox. De acordo com a atividade enzimática e as taxas de germinação, sugere que o método de secagem rápida após o priming com óxido nítrico seja o melhor método para Urochloa ruziziensis.

Termos para indexação: qualidade de sementes, nitroprussiato de sódio, condicionamento osmótico.
Journal of Seed Science, v.43, e202143021, 2021

http://dx.doi.org/10.1590/ 2317-1545v43250046

*Corresponding author
E-mail: heloisa.osantos@ufla.br

Received: 3/19/2021.

Accepted: 7/7/2021.

${ }^{1}$ Programa de Pós-Graduação em Fitotecnia, Universidade Federal de Lavras, 37200-900 - Lavras, MG, Brasil.

${ }^{2}$ Universidade Federal de Lavras, 37200-900 - Lavras, MG, Brasil.

${ }^{3}$ Programa de Pós-Graduação em Fisiologia Vegetal, Universidade Federal de Lavras, 37200-900 Lavras, MG, Brasil. 


\section{INTRODUCTION}

Seed germination is a series of ordered physiological and morphological changes, those involve interactions hormones, metabolism reactivation, repair of DNA and proteins that respond to a set of environmental conditions (Bewley et al., 2013; Xiong et al., 2021). Unfavorable edaphoclimatic conditions such as temperature, during the stages of activation of metabolic processes directly influence germination and uniform establishment of seedlings, consequently affecting productivity (Lima and Marcos-Filho, 2010). On this point, techniques such as osmotic conditioning of seeds have been developed to increase the speed and uniformity of germination and seedling emergence.

The priming is a technique performed during phase I or II of imbibition, with phase I being marked by the rapid water uptake by dry seeds and metabolic processes reactivation. Phase II, or intermediate phase, is marked by reduced water uptake, intensification of respiratory metabolism and the synthesis and repair of enzymes, DNA and other macromolecules (Bewley et al., 2013). The application of nitric oxide, a reactive gaseous molecule with the capacity to regulate different biological and physiological functions in plants, has emerged as an important signaling molecule indicated that the application of exogenous, confers tolerance to various abiotic stresses (Gill et al.,2013; Hasanuzzaman and Fujita, 2013; Farnese et al., 2017).

The exogenous application of nitric oxide (NO) in the form of sodium nitroprusside can positively affect seed germination, both in speed and quantity, in addition to increasing the activity of enzymes of the antioxidant system (Faraji and Sepehri, 2019), interacting with others signaling molecules as the ROS which affects phenological events and stress adaptation (Fancy et al., 2017). NO favours the breaking of seed dormancy in some species and favours the development and elongation of adventitious roots (Silva et al., 2017; Faraji and Sepehri, 2019; Pereira et al., 2020). It can also reduce the effects of ageing of stored seeds, as well as increase tolerance as a protection against various abiotic stresses, such as water, salt, and heavy metal stress (Pereira et al., 2020; Oliveira et al., 2021).

Careful reduction of the water content after osmotic priming is extremely important to maintain the benefits achieved during the treatment and to establish an adequate water level for seed storage (Silva et al., 2020). The use of saturated saline solutions, in a process known as slow drying that keeps the ambient relative humidity constant, has gained prominence. In closed containers, saturated saline solutions provide a constant vapor pressure at a certain temperature (Ducatti et al., 2016). Other methods that can be used are the dry heat sterilization method, which allows us to control the air temperature to within a narrow range inside the chamber, and silica gel (ultradrying), which, in addition to its advantage of allowing rapid drying, allows the observation of the colour variation of silica according to the change in moisture content (Ducatti et al., 2016).

High temperatures can be a stress factor for seeds affecting their germination as reported by Pinto et al. (2021) who tested the temperature of $41{ }^{\circ} \mathrm{C}$ for Urochloa ruziziensis. Due to these potential effects of post priming drying, it is necessary to adapt the procedure to the species and the physiological potential of the lot used (Oliveira et al., 2021). At the cellular level, membranes and proteins can be damaged by reactive oxygen species (ROS) due changes in levels, resulting in enzymatic inactivation (Hu et al., 2012). In ideal conditions, the levels of ROS are regulated by enzymatic and non-enzymatic antioxidants (Mittler, 2017; Morscher et al., 2015) however, the excessive accumulation of these molecules can lead to oxidative stress. Enzymes, such as superoxide dismutase (SOD), catalase (CAT) and ascorbate peroxidase APX act regulating ROS accumulation and minimizing oxidative damage (Kaur et al., 2019). The enzymatic inactivation, and reduced energy metabolism and consequent increase of ROS results lipid peroxidation is one of the main source of deterioration of seeds (Hu et al., 2012).

Forage species have been used in an extractive manner and in cultivated pasture as the main food source of the cattle herd. Among them, the genus Urochloa presents a diversity of species with different recommendations depending on the region where it is grown (Paula et al., 2017). This study aimed to evaluate the effect of seed priming with sodium nitroprusside and to define the best drying method that allows the maintenance of the changes of this treatment in Urochloa ruziziensis seeds. 


\section{MATERIAL AND METHODS}

\section{Plant material and physiological priming}

The experiment was conducted at the Central Laboratory of Seed Analysis, Universidade Federal de Lavras. The seeds used were Urochloa ruziziensis, provided by the company Mineirão Sementes LTDA, produced in the $2017 / 2018$ harvest.

Seeds with $8 \%$ water content were primed in a solution containing sodium nitrite as an NO donor at a concentration of $0.10 \mathrm{mmol} . \mathrm{L}^{-1}$ for 42 hours. A total of 40 grams of seeds were placed in $400 \mathrm{~mL}$ of the solution (Oliveira et al., 2021). During priming, the seeds were kept in biochemical oxygen demand (BOD) germinators at $25{ }^{\circ} \mathrm{C}$ without light and adapted with an air compressor that kept the solutions aerated.

After priming, the seeds were washed in running water, and the excess water was removed by centrifugation. The seeds used as a control did not undergo any method of priming or drying.

\section{Seed drying}

For drying, ten treatments were used with three replicates each. The treatments were: slow drying (SD); rapid drying (RD); thermal shock + slow drying (TSSD); thermal shock + rapid drying (TSRD); water content reduction + slow drying ( $r S D)$; water content reduction + rapid drying ( $r R D)$; water content reduction + thermal shock + slow drying (rTSSD); water content reduction + thermal shock + rapid drying (rTSRD); control treatment (seeds without priming and drying); and priming without drying (WD).

For SD, a saturated magnesium chloride $(32 \% \mathrm{RH})$ solution was used, and for $\mathrm{RD}$, a saturated saline solution of lithium chloride $(12 \% \mathrm{RH})$ was used. To obtain both solutions, the salt was added to distilled water until the saturation point was reached.

The seeds were distributed evenly inside plastic boxes (Gerbox) with individual compartments (mini-chambers) and a tray with an aluminium screen inside. To each individual compartment was added $40 \mathrm{~mL}$ of each saturated solution. The plastic boxes were kept in a BOD incubator at $25^{\circ} \mathrm{C}$ for 48 hours.

For TSSD and TSRD, before SD or RD, the seeds were placed at a temperature of $35^{\circ} \mathrm{C}$ for forty minutes for the thermal shock treatment, maximum temperature recommended during desiccation. Seeds were weighed after priming and weighed every minute until they reached a reduction of $10 \%$ from the initial weight.

After drying, all seeds remained in a controlled environment for 48 hours, with air circulation at $25^{\circ} \mathrm{C}$, to standardize the water content of the seeds.

\section{Water content}

The water content was determined before seed priming, before drying, and after drying. For this purpose, four replicates of 2 grams of seeds were used as samples. The seeds were weighed and then dried in an oven at $105 \pm 3{ }^{\circ} \mathrm{C}$ for 24 hours (Brasil, 2009). The results are presented as percentages based on the wet weight.

\section{Germination test and seedling establishment}

The germination test was performed with four replicates of fifty seeds. Two sheets of blotting paper moistened with deionized water with a volume of water equivalent to 2.5 times the dry weight of the paper were used as substrate. The germination boxes containing the substrate and seeds were kept in BOD incubators with an alternating temperature of $20-35^{\circ} \mathrm{C}$ and eight hours with light and sixteen hours in the dark (Brasil, 2009). The germination speed index was calculated according to Maguire (1962), whit daily evaluations during 21 days. The results of germination are expressed as the percentage of seeds that had germinated by seven (first count) and 21 days (final germination) after the beginning of the test (Brasil, 2009). 


\section{Emergence test}

The emergence test was performed in a soil:sand substrate at a volume ratio of 1:2 in plastic trays maintained in a controlled environment $\left(25{ }^{\circ} \mathrm{C}\right.$ and 12 -hour photoperiod). Four replicates of fifty seeds per treatment were used. The results of the initial stand were evaluated at seven days (initial stand) and the emergence one at 21 days after the start of the test and are expressed in percentage of normal seedlings (Brasil, 2009). The emergence speed index (Maguire, 1962) was calculated at the same time as the emergence test, with daily evaluations. A plant was deemed to have emerged as soon as the coleoptile broke through the soil.

\section{Enzymes of the antioxidant system}

The activities of antioxidant enzymes (CAT, SOD, and APX) were evaluated in the seeds after physiological priming and drying. The enzymatic extracts were obtained from $0.2 \mathrm{~g}$ of fresh mass macerated in liquid nitrogen and insoluble polyvinylpolypyrrolidone supplemented with $1.5 \mathrm{~mL}$ of extraction buffer containing $400 \mathrm{mM}$ potassium phosphate buffer (pH 7.8), $10 \mathrm{mM}$ EDTA, and $200 \mathrm{mM}$ ascorbic acid. The extract was centrifuged at $13.000 \mathrm{~g}$ for ten minutes at $4{ }^{\circ} \mathrm{C}$ (Biemelt et al., 1998). The supernatant was taken to quantify SOD, CAT, and APX activities.

SOD activity was estimated by the ability of the enzyme to inhibit the photoreduction of nitro blue tetrazolium (NBT) (Giannopolitis and Ries, 1977). The readings were performed at $560 \mathrm{~nm}$. One unit of SOD corresponds to the amount of enzyme capable of inhibiting NBT photoreduction by $50 \%$ under the test conditions. CAT activity was determined according to Havir and McHale (1987). The activity of this enzyme was measured by the decrease in absorbance at 240 $\mathrm{nm}$ every fifteen seconds for three minutes, determined by the consumption of hydrogen peroxide. The molar extinction coefficient used was $36 \mathrm{mM}^{-1} . \mathrm{cm}^{-1}$, as described by Azevedo et al. (1998). APX activity was determined according to Nakano and Asada (1981) by monitoring the oxidation rate of ascorbate at $290 \mathrm{~nm}$, and the molar extinction coefficient used was $2.8 \mathrm{mM}^{-1} \cdot \mathrm{cm}^{-1}$.

\section{Statistical procedures}

The results were subjected to analysis of variance $(p<0.05)$ and Scott-Knott test in the SISVAR statistical program (Ferreira, 2014).

\section{RESULTS AND DISCUSSION}

All treatments that went through the drying processes reduced the water content between $11.10 \%$ and $13.19 \%$. The WD treatment, for not having gone through the drying process, remained with $37.42 \%$ of water content (Table 1 ). Masetto et al. (2013) also conducted experiments with Urochloa ruziziensis seeds and reduced water contents by $9.5 \%$, $11.3 \%$ and $14.6 \%$ to assess germination potential and it was found that the two highest water contents tested provided higher germination percentages (average of up to 70\%) when compared $9.5 \%$ of the water content which had the lowest germination percentage with $20 \%$. Thus, for Urochloa ruziziensis seeds, the reduction of water content by up to $11 \%$ does not negatively impact the reactivation of metabolism and germination processes.

The rRD treatment and the WD treatment showed similar values of the first germination count, both higher than the others. The rSD treatment showed the same value as the control treatment, being higher than the SD, RD, TSRD, rTSRD, and rTSSD treatments, which in turn had higher values than the TSSD treatment (Table 1).

The rRD and control treatments had the highest germination percentages. The treatments RD, TSRD, rSD, and WD showed equal means, which were higher than those of the SD, TSSD, rTSSD, and rTSRD treatments (Table 1). The SD, rSD, rRD, WD, and control treatments had similar germination speed index values, followed by the RD, TSSD, TSRD, rTSSD, and rTSRD treatments (Table 1).

The control treatment had the highest percentage of emerged seedlings in the first count. The SD, RD, rSD, rRD, rTSSD, rTSRD, and WD groups showed means equal to each other, which were higher than those of the TSSD and TSRD 
treatments (Table 1). The TSRD and rTSRD treatments showed emergence percentages equal to each other and lower than those of the other treatments (Table 1).

The WD seeds showed the same emergence speed index as the SD treatment, which were the highest values obtained. The RD, rSD, SRD, and control treatments had statistically equal, intermediate emergence rate index values, followed by the rTSSD and rTSRD treatments, which were equal to each other. The TSSD and TSRD treatments had the lowest emergence speed index value (Table 1).

Osmotic priming promoted the slow imbibition of Urochloa seeds and maintained enough hydration control to allow the metabolic processes essential for germination. As can be seen, the imbibition of the analyzed seeds was sufficient to promote germination in the drying conditions evaluated and, observing the results of the enzymatic activity of the antioxidant system, NO promoted a better activity of these, thus helping to maintain redox homeostasis with the reactivation of metabolism. According to Ribeiro et al. (2019), the absorption of water by seeds activates metabolism, and the more water is available, the more pre-germination processes can be activated.

By providing slow and controlled seed hydration, NO priming enables the recovery of the cell membrane system and the repair of DNA and other macromolecules, providing greater germination uniformity and speed (Bewley et al., 2013). In addition, NO is directly involved in the perception and transduction of signals related to plant hormones abscisic acid and gibberellins and is thus involved in the regulation of the balance of germination inducers and repressors (Sami et al., 2018; Castillo-Aguilar et al., 2017). Thus, the groups that were submitted to priming and slow drying showed higher GSIs, and higher percentages of germination.

After the drying treatments, the water content in the seed was stabilized at the levels recommended for storage and sale (Ribeiro et al., 2019). After priming, the drying treatments put the seeds at the moisture content observed before the process started, without losing the activation of metabolism gained by imbibition, which will allow these seeds to be stored for a certain time until sowing (Wojtyla et al., 2016).

The effects of priming and drying were evidenced in the vigour of Urochloa seeds, represented by the first count in the germination test in the treatment with initial reduction of the water content combined with rapid drying. The

Table 1. Water content, first germination count, germination, germination speed index (GSI), initial stand, emergence percentage, and emergence speed index (ESI) of Urochloa ruziziensis seeds subjected to different drying methods after osmotic priming.

\begin{tabular}{cccccccc}
\hline & Water content & First germination count & Germination & GSI & Initial stand & Emergence & ESI \\
\hline SD & 12.28 & $58 \mathrm{C}$ & $68 \mathrm{C}$ & $6.20 \mathrm{~A}$ & $38 \mathrm{~B}$ & $80 \mathrm{~A}$ & $8.19 \mathrm{~A}$ \\
$\mathrm{RD}$ & 12.29 & $52 \mathrm{C}$ & $76 \mathrm{~B}$ & $5.66 \mathrm{~B}$ & $37 \mathrm{~B}$ & $78 \mathrm{~A}$ & $7.47 \mathrm{~B}$ \\
TSSD & 12.69 & $43 \mathrm{D}$ & $64 \mathrm{C}$ & $5.17 \mathrm{~B}$ & $32 \mathrm{C}$ & $74 \mathrm{~A}$ & $6.24 \mathrm{D}$ \\
TSRD & 12.92 & $55 \mathrm{C}$ & $78 \mathrm{~B}$ & $5.01 \mathrm{~B}$ & $31 \mathrm{C}$ & $67 \mathrm{~B}$ & $6.05 \mathrm{D}$ \\
rSD & 11.10 & $64 \mathrm{~B}$ & $76 \mathrm{~B}$ & $6.77 \mathrm{~A}$ & $37 \mathrm{~B}$ & $76 \mathrm{~A}$ & $7.26 \mathrm{~B}$ \\
rRD & 12.33 & $78 \mathrm{~A}$ & $87 \mathrm{~A}$ & $6.99 \mathrm{~A}$ & $37 \mathrm{~B}$ & $76 \mathrm{~A}$ & $7.54 \mathrm{~B}$ \\
rTSSD & 13.19 & $56 \mathrm{C}$ & $68 \mathrm{C}$ & $5.47 \mathrm{~B}$ & $37 \mathrm{~B}$ & $74 \mathrm{~A}$ & $6.90 \mathrm{C}$ \\
rTSRD & 12.41 & $54 \mathrm{C}$ & $66 \mathrm{C}$ & $5.36 \mathrm{~B}$ & $36 \mathrm{~B}$ & $69 \mathrm{~B}$ & $6.98 \mathrm{C}$ \\
WD & 37.42 & $74 \mathrm{~A}$ & $74 \mathrm{~B}$ & $7.18 \mathrm{~A}$ & $35 \mathrm{~B}$ & $78 \mathrm{~A}$ & $8.64 \mathrm{~A}$ \\
Cont & 11.25 & $63 \mathrm{~B}$ & $86 \mathrm{~A}$ & $6.26 \mathrm{~A}$ & $42 \mathrm{~A}$ & $83 \mathrm{~A}$ & $7.57 \mathrm{~B}$ \\
\hline CV (\%) & & 7.73 & 8.42 & 11.97 & 7.15 & 5.99 & 7.17 \\
\hline
\end{tabular}

Means followed by the same letter do not differ by the Scott-Knott test at $5 \%$ probability.

SD: slow drying; RD: rapid drying; TSSD: thermal shock and slow drying; TSRD: thermal shock with rapid drying; rSD: water content reduction and slow drying; rRD: water content reduction and rapid drying; rTSSD: water content reduction, thermal shock, and slow drying; rTSRD: water content reduction, thermal shock and rapid drying; WD: seeds primed without drying; Cont: control. 
application of NO donors has a protective role in the seeds, thereby inducing a higher and faster germination rate (Kaiser et al., 2016). In this study, similar results were observed where the control treatment presented a lower initial germination count (First germination count) when compared to the WD and rRD treatments, the latter having a faster initial germination speed. After the first count, the control and rRD treatments had similar germination rate and GSI.

The rSD treatment had a significantly higher mean SOD activity than all other treatments. The treatments RD, TSRD, and rTSSD and WD did not differ significantly from each other and showed greater SOD activity than the control, followed by treatments SD, TSSD, rRD, and lastly rTSRD. The control treatment had the lowest mean enzymatic activity (Figure $1 \mathrm{~A}$ ).

The TSSD and rTSRD treatments presented the highest mean CAT activity, followed by the RD, TSRD, rSD, and rTSSD treatments. The rRD and control treatments had equal means. The lowest means were obtained for the SD and groups (Figure 1B).

APX activity reached the highest means in the RD, TSSD, and rRD treatments, followed by TSRD, rSD, and rTSRD. The SD treatment and WD obtained statistically equal means to the control treatment. The lowest enzymatic activity was observed in the rTSSD treatment (Figure 1C).

In addition to signaling molecules, some heat shock proteins are related to the prevention of denaturation of macromolecules in the upregulated turgor and cellular dehydration processes. However, dry seeds, according to José et al. (2005), do not have a specific set of heat-resistance proteins. This claim is in agreement with the results found here, where the thermal shock of $35^{\circ} \mathrm{C}$ for forty minutes reduced the emergence of Urochloa seedlings relative to the seedlings in the group that did not undergo heat shock treatment. The processes triggered by high-temperature stress can produce changes in protein metabolism and consequently oxidative stress due to the production of ROS (Gimalov et al., 1996).

In fact, imbibition, controlled or not, leads to an increase in the activity of respiratory metabolism, which consequently intensifies the production of ROS and thus stimulates antioxidant pathways to maintain redox homeostasis (Gomes et al., 2013). During germination, NO mainly assists on signaling related to interactions with cellular targets through the

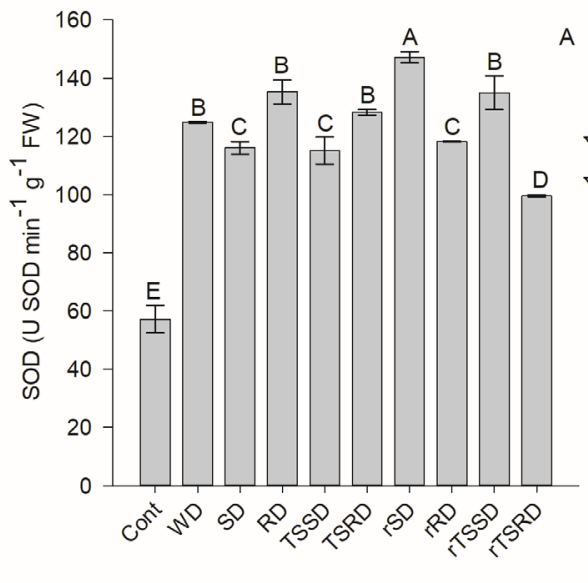

TREATMENTS

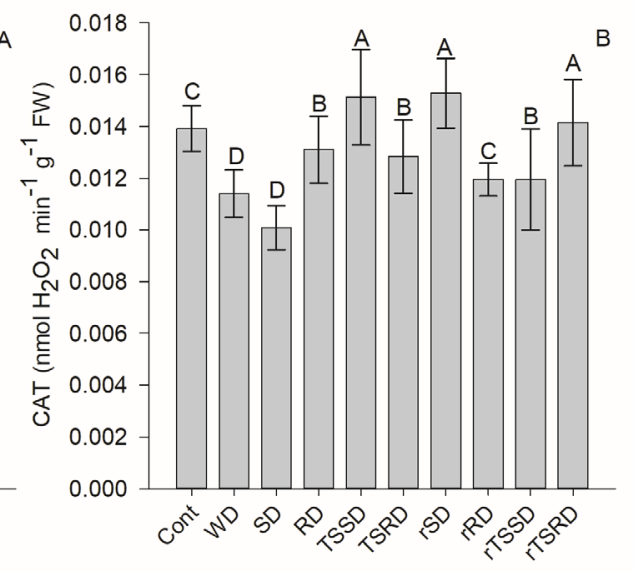

TREATMENTS

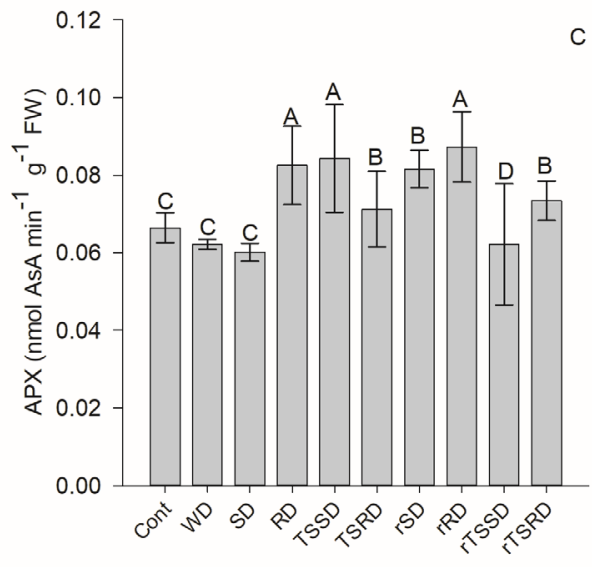

TREATMENTS

SD: slow drying; RD: rapid drying; TSSD: thermal shock and slow drying; TSRD: thermal shock with rapid drying; rSD: water content reduction and slow drying; rRD: water content reduction and rapid drying; rTSSD: water content reduction, thermal shock, and slow drying; rTSRD: water content reduction, thermal shock, and rapid drying; WD: seeds primed without drying; Cont: control.

Bars are means \pm standard error $(n=4)$.

Uppercase letters compare the activity of SOD, CAT or APX in each treatment. Equal letters do not differ from each other on Scott-Knott test set at $5 \%$ of probability.

Figure 1. (A) Superoxide dismutase, (B) catalase activity, and (C) ascorbate peroxidase activity in Urochloa ruziziensis seeds subjected to different drying methods after osmotic priming. 
establishment of redox homeostasis and is considered a protective molecule (Silva et al., 2020). The treatments rRD showed better performance in the observed germination parameters. Once the respiratory and energy metabolism of seeds subjected to physiological priming is reactivated, homeostasis between the production and elimination of ROS must be maintained, thus ensuring cell vigour and integrity. The extent of ROS accumulation and the extent of the damage they cause are determined by the antioxidant system, which preserves the integrity of proteins, lipids, and other cellular components so that they can participate in metabolism (Foyer and Noctor, 2005).

SOD is the first enzyme that acts in the defence of the organism against ROS. SOD is considered a key enzyme in keeping the intracellular concentrations of superoxide and peroxide radicals at levels nontoxic to cells (Borjas Ventura et al., 2019). The highest SOD activities were observed in the rSD, TSRD, and RD treatments, and the other enzymes also showed high activity, indicating that the entire antioxidant system was activated to reduce oxidative stress. The treatments rTSSD and priming without drying showed high SOD activity. The slow drying (magnesium chloride) treatment in Urochloa seeds was associated with low activity of the enzymes SOD, CAT, and APX compared to the other treatments. This indicates that this type of drying does not induce ROS generation and therefore has low oxidative stress.

CAT is effective, especially at relatively high $\mathrm{H}_{2} \mathrm{O}_{2}$ concentrations, and is therefore considered indispensable for the detoxification of ROS when $\mathrm{H}_{2} \mathrm{O}_{2}$ levels are high, a trait observed in Urochloa seeds subjected to treatments TSSD and rTSRD, which showed the highest activity of this enzyme. CAT inhibition, on the other hand, leads to the accumulation of ROS, generating oxidative stress, which can hinder seedling development or even cause cell death (Borjas Ventura et al., 2019). Low CAT activity was observed in the treatments WD, SD, and rRD. However, it is not possible to correlate these results with the increase in oxidative stress because, especially in the rRD treatment, the germination percentage was high.

Both SOD and CAT are involved in a protective mechanism responsible for the elimination of toxic products from the cells, keeping them at controlled levels. Thus, to maintain the balance of ROS at the intracellular level, these enzymes must act in a joint and integrated manner (Mittler, 2017).

APX plays a key role in the ascorbate-glutathione cycle and in the elimination of $\mathrm{H}_{2} \mathrm{O}_{2}$ from the chloroplasts and cytosol of plant cells. This enzyme plays an important role in cell wall biosynthesis, as well as in cell growth, differentiation, and development, in addition to being involved in stress responses (Bewley et al., 2013). The RD, TSSD, and rTSRD treatments had active APX and CAT. This cooperative action occurs in $\mathrm{H}_{2} \mathrm{O}_{2}$ dismutation events, optimizing the mitigation of the deleterious effects of the ROS generated under stress conditions (Borjas Ventura et al., 2019). Under the rRD treatment, the enzymatic activity of APX was high, but the other enzymes were not active. This same treatment showed the highest germination percentage, indicating the efficiency of the antioxidant system in the removal of oxidative radicals.

\section{CONCLUSIONS}

All drying methods applied to the seeds of Urochloa ruziziensis after physiological priming reduced the water content to the recommended storage range. Regarding priming with sodium nitroprusside, for the germination parameters GSI, germination and emergence, no significant results were observed when comparing the control treatment to the others. However, when the first germination count was observed, it was observed that the rRD treatment presented better performance. As for the drying methods after priming, the treatment water content reduction + rapid drying (rRD) were the best methods applied for the drying of Urochloa ruziziensis.

\section{ACKNOWLEDGMENT}

The authors would like to thank CAPES (Coordenação de Aperfeiçoamento de Pessoal de Nível Superior), CNPq (Conselho Nacional de Desenvolvimento Científico e Tecnológico -426309/2018-9) and FAPEMIG (Fundação de Amparo à Pesquisa do Estado de Minas Gerais) for the financing and research grants granted to conduct this study. 


\section{REFERENCES}

AZEVEDO, R.A.; ALAS, R.M.; SMITH, R.J.; LEA, P.J. Response of antioxidant enzymes to transfer from elevated carbon dioxide to air and ozone fumigation, in the leaves and roots of wild-type and a catalase-deficient mutant of barley. Physiologia Plantarum, v.104 n.2, p.280-292, 1998. https://doi.org/10.1034/j.1399-3054.1998.1040217.x

BEWLEY, J.D.; BRADFORD, K.J.; HILHORST, H.W.M.; NONOGAKI, H. Seeds: physiology of development, germination and dormancy. $3^{\text {rd }}$ ed. New York: Springer, 2013. 392p.

BIEMELT, S.; KEETMAN, U.; ALBRECHT, G. Re-aeration following hypoxia or anoxia leads to activation of the antioxidative defense system in roots of wheat seedlings. Plant Physiology, v.116, n.2, p.651-658, 1998. http://www.plantphysiol.org/ content/116/2/651.short

BORJAS VENTURA, R.; MENDOZA SOTO, V.; JULCA OTINIANO, A.; LUPINO GRATÃO, P. Effect of water stress and temperature increase on productive, physiological and biochemical variables of "cacao" Theobroma cacao L. Arnaldoa, v.26, n.1, p.287-296, 2019. http:// www.scielo.org.pe/scielo.php?script=sci_arttext\&pid=\$2413-32992019000100012

BRASIL. Ministério da Agricultura, Pecuária e Abastecimento. Regras para análise de sementes. Ministério da Agricultura, Pecuária e Abastecimento. Secretaria de Defesa Agropecuária. Brasília: MAPA/ACS, 2009. 399p. http:// https://www.gov.br/agricultura/ptbr/assuntos/insumos-agropecuarios/arquivos-publicacoes-insumos/2946_regras_analise_sementes.pdf

CASTILLO-AGUILAR, C.C.; DOLZ-RAMOS, R.; ARREOLA-ENRÍQUEZ, J.; CARBAJAL-LEÓN, J.E.; CARRILLO-CASTAÑEDA, G.; COH-MÉNDEZ, D.; CARRILLO-ÁVILA, E. Evaluation of rhizobacteria strains in the production of habanero chili (Capsicum chinense Jacq.) seedlings. Agroproductividad, v.10, p.128-133, 2017. https://www.cabdirect.org/cabdirect/abstract/20193017782

DUCATTI, K.R.; SILVA, J.; COIMBRA, R.D.A. Metodologias de ajuste do teor de água em sementes de milho doce para o teste de envelhecimento acelerado. Revista Brasileira de Milho e Sorgo, v.15, n.1, p.145-156, 2016. http://rbms.cnpms.embrapa.br/index. php/ojs/article/view/645

FANCY, N.N.; BAHLMANN, A.K.; LOAKE, G.J. Nitric oxide function in plant abiotic stress. Plant, Cell and Environment, v.40, p.462-472, 2017. https://onlinelibrary.wiley.com/doi/full/10.1111/pce.12707

FARAJI, J.; SEPEHRI, A. Ameliorative effects of $\mathrm{TiO}_{2}$ nanoparticles and sodium nitroprusside on seed germination and seedling growth of wheat under PEG-stimulated drought stress. Journal of Seed Science, v.41, n.3, p.309-317, 2019. https://www.scielo.br/ scielo.php?pid=S2317-15372019000300309\&script=sci_arttext

FARNESE, F.S.; OLIVEIRA, J.A.; PAIVA, E.A.S.; MENEZES-SILVA, P.E.; SILVA, A.A.; CAMPOS, F.V.; RIBEIRO, C. The involvement of nitric oxide in integration of plant physiological and ultrastructural adjustments in response to arsenic. Frontiers in Plant Science, v.8, p.516, 2017. https://www.frontiersin.org/articles/10.3389/fpls.2017.00516/full

FERREIRA, D. Sisvar: a guide for its bootstrap procedures in multiple comparisons. Ciência e Agrotecnologia, v.32, n.2, p.109-112, 2014. https://doi.org/10.1590/S1413-70542014000200001

FOYER, C.; NOCTOR, G. Redox homeostasis and antioxidant signaling: a metabolic interface between stress perception and physiological responses. The Plant Cell, v.17, n.7, p.1866-875, 2005. http://www.plantcell.org/content/17/7/1866.short

GIANNOPOLITIS, C.N.; RIES, S.K. Superoxide dismutases I. Occurrence in higher plants. Plant Physiology, v.59, n.2, p.309-314, 1977. http://www.plantphysiol.org/content/59/2/309.short

GILL, S.S.; HASANUZZAMAN, M.; NAHAR, K.; MACOVEI, A.; TUTEJA, N. Importance of nitric oxide in cadmium stress tolerance in crop plants. Plant Physiology and Biochemistry, v.63, p.254-261, 2013. https://www.sciencedirect.com/science/article/abs/pii/ S0981942812003488

GIMALOV, F.P.; CHEMERIS, A.V.; VAKHITOV, V.A. Synthesis of cold shock proteins in wheat tribe seedlins of the family Poaceae. Russian Journal of Plant Physiology, v.43, n.1, p.228-231, 1996. https://elibrary.ru/item.asp?id=13238890

GOMES, M.P.; CARNEIRO, M.M.L.C.; NOGUEIRA, C.O.G.; SOARES, A.M.; GARCIA, Q.S. The system modulating ROS content in germinating seeds of two Brazilian savanna tree species exposed to As and Zn. Acta Physiologiae Plantarum, v.35, n.4, p.1011-1022, 2013. https://link.springer.com/article/10.1007\%2Fs11738-012-1140-6 
HASANUZZAMAN, M.; FUIITA, M. Exogenous sodium nitroprusside alleviates arsenic induced oxidative stress in wheat (Triticum aestivum L.) seedlings by enhancing antioxidant defense and glyoxalase system. Ecotoxicology, v.22, p.584-96, 2013. https://link. springer.com/article/10.1007/s10646-013-1050-4

HAVIR, E.A.; MCHALE, N.A. Biochemical and developmental characterization of multiple forms of catalase in tobacco leaves. Plant Physiology, v.67, n.3, p.450-455, 1987. http://www.plantphysiol.org/content/84/2/450.short

HU, D.; MA, G.; WANG, Q.; YAO, J.; WANG, Y.U.; PRITCHARD, H.W.; WANG, X. Spatial and temporal nature of reactive oxygen species production and programmed cell death in elm (Ulmus pumila L.) seeds during controlled deterioration. Plant, Cell and Environment, v.35, n.11, p.2045-2059, 2012. https://onlinelibrary.wiley.com/doi/full/10.1111/j.1365-3040.2012.02535.x

JOSE, S.C.B.R.; VON PINHO, E.V.R.; VON PINHO, R.G.; SILVEIRA, C.M. Padrão eletroforético de proteínas resistentes ao calor em sementes de milho. Pesquisa Agropecuária Brasileira, v.40, n.2, p.115-121, 2005. https://www.scielo.br/scielo.php?pid=S0100204X2005000200003\&script=sci_arttext\&tlng=pt

KAISER, D.K.; MALAVASI, M.M.; MALAVASI, U.C.; DRANSKI, J.A.L.; FREITAS, L.C.N.; KOSMAN, C.R.; ANDRIOLI, K.K. Physiological maturity of seeds and colorimetry of the fruits of Allophylus edulis. Journal of Seed Science, v.38, n.2, p.92-100, 2016. https://www. scielo.br/scielo.php?pid=S2317-15372016000200092\&script=sci_arttext

KAUR, N.; KAUR, J.; GREWAL, S.K.; SINGH, I. Effect of heat stress on antioxidative defense system and its amelioration by heat acclimation and salicylic acid pre-treatments in three pigeonpea genotypes. Indian Journal of Agricultural Biochemistry, v.32, n.1, p.106-110, 2019. https://www.indianjournals.com/ijor.aspx?target=ijor:ijab\&volume=32\&issue=1\&article=014

LIMA, L.B.; MARCOS-FILHO, J. Condicionamento fisiológico de sementes de pepino e germinação sob diferentes temperaturas. Revista Brasileira de Sementes, v.32, n.1, p.138-147, 2010. https://www.scielo.br/scielo.php?pid=S0101-31222010000100016\&script=sci_ arttext\&tIng=pt

MAGUIRE, J.D. Speed of germination-aid in selection and evaluation for seedling emergence and vigor. Crop Science, v.2, n.1, 1962.

MASETTO, T.E.; RIBEIRO, D.M.; REZENDE, R.K.S. Germinação de sementes de Urochloa ruziziensis em função da disponibilidade hídrica do substrato e teor de água das sementes. Pesquisa Agropecuária Tropical, v.43, n.4, p.385-391, 2013. https://www.scielo. $\mathrm{br} / \mathrm{j} / \mathrm{pat} / \mathrm{a} / \mathrm{R} 9 \mathrm{bLv34Lf6F8BmvZBjC8KPm/?lang=pt}$

MITTLER, R. ROS are good. Trends in Plant Science, v.22, n.1, p.11-19, 2017. https://www.sciencedirect.com/science/article/pii/ S1360138516301121

MORSCHER, F.; KRANNER, I.; ARC, E.; BAILLY, C.; ROACH, T. Glutathione redox state, tocochromanols, fatty acids, antioxidant enzymes and protein carbonylation in sunflower seed embryos associated with after-ripening and ageing. Annals of Botany, v.116, n.4, p.669-678, 2015. https://academic.oup.com/aob/article/116/4/669/94274?login=true

NAKANO, Y.; ASADA, K. O peróxido de hidrogênio é eliminado pela peroxidase específica do ascorbato em cloroplastos de espinafre. Fisiologia Vegetal e Celular, v.22, n.5, p.867-880, 1981.

OLIVEIRA, T.F.; SANTOS, H.O.D.; VAZ-TOSTES, D.P.; CAVASIN, P.Y.; ROCHA, D.K.; TIRELLI, G.V. Protective action of priming agents on Urochloa brizantha seeds under water restriction and salinity conditions. Journal of Seed Science, v.43, 2021. https://www.scielo. $\mathrm{br} / \mathrm{j} / \mathrm{jss} / \mathrm{a} / \mathrm{yCRZDjSDcPRTxBbfMLhnRxg/?lang=en \& format=html}$

PAULA, L.C.; CEZÁRIO, A.S.; OLIVEIRA, N.C.; LIMA, M.; VIEIRA, J.P.B.; DAMASCENA, E.G.; RABEL, A.P.B.; SANTOS, W.B.R. Manejo e adaptação de pastagens do gênero Urochloa em solos do cerrado. Colloquium Agrariae, v.13, n.Especial, 2017. http://journal. unoeste.br/suplementos/agrariae/vol13nr2/MANEJO\%20E\%20ADAPTA\%C3\%87\%C3\%830\%20DE\%20PASTAGENS\%20DO\%20 G\%C3\%8ANERO\%20UROCHLOA\%20EM\%20SOLOS\%20DO\%20CERRADO.pdf

PEREIRA, T.M.; SANTOS, H.O.; CUNHA-NETO, A.R.; PELISSARI, F.; PEREIRA, W.V.; MELO, L.A.D. Does nitric oxide protect Eucalyptus urophylla seeds under salt stress conditions? Journal of Seed Science, v.42, 2020. https://www.scielo.br/scielo.php?pid=S231715372020000100136\&script=sci_arttext

PINTO, A.H.; BATISTA, T.B.; SILVA BINOTTI, F.F.; BINOTTI, E.D.C.; COSTA, E. Thermal stress in the adequacy of the chemical scarification period in brachiaria seeds. Revista de Agricultura Neotropical, v.8, n.1, p.5753, 2021. https://periodicosonline.uems.br/index.php/ agrineo/article/view/5753/4116 
RIBEIRO, V.H.A.; ALMEIDA, R.L.J.; SANTOS, N.C.; BARROS S.L.; NASCIMENTO, A.P.S. Mathematical modeling of apple drying kinetics. Higiene Alimentar, v.33, p.3474-3478, 2019. https://higienealimentar.com.br/wp-content/uploads/2020/08/AnaisHigienistas-2019_VERS\%C3\%830-ATUALIZADA-FINAL_compressed.pdf

SAMI, F.; SIDDIQUI, H.; HAYAT, S. Interaction of glucose and phytohormone signaling in plants. Plant Physiology and Biochemistry, v.135, p.119-126, 2018. https://www.sciencedirect.com/science/article/abs/pii/S0981942818304923

SILVA, A.; BINOTTI, F.; COSTA, E.; PEREIRA, T.C.; PINTO, A. Sais liberadores de óxido nítrico na emergência e crescimento de seringueira. Enciclopédia Biosfera, v.14, n.25, 2017. http://www.conhecer.org.br/enciclop/2017a/agrar/sais\%20liberadores\%20 de\%20oxido.pdf

SILVA, B.M.C.; OLIVEIRA, D.E.C.; LIMA FARIAS, B.; COSTA, V.S.; FERREIRA, V.B.; NUNES, M.R.G.; RESENDE, O. Influência da secagem na qualidade fisiológica e coloração das sementes de feijão guandu. Research, Society and Development, v.9, n.7, 2020. https:// www.rsdjournal.org/index.php/rsd/article/view/4789

WOJTYLA, Ł.; LECHOWSKA, K.; KUBALA, S.; GARNCZARSKA, M. Different modes of hydrogen peroxide action during seed germination. Frontiers in Plant Science, v.7, p.66, 2016. https://www.frontiersin.org/articles/10.3389/fpls.2016.00066/full

XIONG, M.; CHU, L.; LI, Q.; YU, J.; YANG, Y.; ZHOU, P.; ZHOU, Y.; ZHANG, C.; FAN, X.; ZHAO, C.; YAN, C.; LIU, Q. Brassinosteroid and gibberellin coordinate rice seed germination and embryo growth by regulating glutelin mobilization. The Crop Journal, 2021. https://www.sciencedirect.com/science/article/pii/S2214514121000039 use, distribution, and reproduction in any medium, provided the original work is properly cited. 